DOI: https://doi.org/10.32838/2523-4803/70-2-44

UDC 339.138

\title{
Seleznova Olha
}

Doctor of Economic Sciences, Associate Professor,

Professor at the Department of Marketing and Business Administration,

Odesa I.I. Mechnikov National University

\section{Nataliya Shyriaieva}

Candidate of Technical Sciences, Associate Professor,

Associate Profesor at the Department of Management and Marketing,

Odessa State Academy of Civil Engineering and Architecture

\section{Strenkovska Anna}

Candidate of Economic Sciences,

Associate Professor at the Department of Economics and Engineering,

Odessa State Academy of Civil Engineering and Architecture

\section{Селезньова 0.0 .}

доктор економічних наук, доцент,

професор кафедри маркетингу та бізнес-адміністрування,

Одеський національний університет імені I. I. Мечникова

\section{Ширяева Н.Ю.}

кандидат технічних наук, доцент,

доцент кафедри менеджменту і маркетингу,

Одеська державна академія будівництва та архітектури

Стренковська А.Ю.

кандидат економічних наук,

доцент кафедри економіки та підприємництва,

Одеська державна академія будівництва та архітектури

\section{SCRUM-TECHNOLOGY IN THE MANAGEMENT OF MARKETING ACTIVITIES OF A CONSTRUCTION ENTERPRISE}

In the article there have been brought theoretical and applied bases of introduction of Scrum-technology into the management of marketing activity of the construction enterprise. The definition of the process of management of marketing activities of the construction enterprise has been given. There has been shown a historical background of the emergence of Scrum-technology in the field of enterprise's management. The content of essence of Scrum-technology is revealed and its suitability in the management of marketing activity of the construction enterprise is proved. The main components of Scrum-technology, as well as the principles of its work, are named and described. A brief description of the web-system for the implementation of Scrum-technology at the construction enterprise is given. The main stages of implementation of Scrumtechnology in the management of marketing activity of the construction enterprise are proved. An example of the implementation of Scrum-technology at the Ukrainian construction enterprise LLC "Alfapivdenbud" is shown.

Key words: Scrum-technology, scrum master, scrum team, marketing activity, construction enterprise, project management.

Formulation of the problem. In modern conditions of conducting construction business, when the speed of decision-making and customers' satisfaction are the defining value, the operational teamwork of the enterprise, the use of the latest construction technologies, the use of the Internet communications and the like is gaining more and more importance in the management.

The scientists agree that a significant proportion of processes in various fields of activity tends to integrate, that is, occurs at the junctures of Sciences. The theory of the management in the field of information technology happened to have been formed independently from the general management theories, therefore, it has acquired unique features, the practice with which one should get acquainted, and partly borrow in other areas, including economic ones. This approach can reform the management system and add new methods of the management of marketing activities of enterprises in the construction industry.

The authors of this work consider the management of marketing activities of construction enterprises as a process of the management of business entity of the construction sphere with the aim of achieving commercial results 
by the satisfaction of consumers' needs of the construction market through development and implementation of relevant production concerning existing demand [1].

Therefore, we believe that the timeliness of realization construction projects and compliance with customers' expectations depends on the qualified management of marketing activities of the enterprise. The leading place in this process is occupied by well-coordinated teamwork of employees. To solve this problem, special attention should be paid to different approaches to production and support of functionally complex products, which are building structures and constructions. One of the approaches, that deserves special attention of construction enterprises, is Scrum-technology.

Analysis of recent research and publications. Ikujiro Nonaka and Hirotaka Takeuchi, in an article "The New Product Development Game" (Harvard Business Review, January-February of 1986), noted that projects worked on by small teams of specialists in various fields tend to produce better results systematically, and explained this as a "rugby approach".

In 1991, Leslie Hulet Stahl in a book "Wicked Problems, Righteous Solutions" [2] called this approach by the word "scrum" ("fight" in a rugby terminology).

In the early 1990s, Ken Schwaberused used an approach that subsequently brought SCRUM to his company.

For the first time, the SCRUM methodology was presented to the public as documented, articulated and described one jointly by Ken Schwaber and Jeff Sutherland at the OOPSLA in Austin, 1995 [3].

Since 1990s, SCRUM has been widely used around the world to: 1. Explore and identify potential markets, technologies and product opportunities. 2. Develop products and improve them. 3. Produce products and improve them several times a day. 4. Develop and maintain cloud (online, secure, on demand) and other operating environments for the product. 5. Maintain and update products.

Ken Schwaber and Jeff Sutherland have worked together over the years to process and describe all their experiences and best practices for the industry together, into the methodology, which is known today as SCRUM.

Ken Schwaber joined forces with Mike Beedle in 2001 to describe in the book the method in detail "Agile Software Development with SCRUM" [4].

In 2002, Schwaber co-founded the Scrum Alliance [5] and created a series of certified Scrum accreditations. Schwaber left the Scrum Alliance at the end of 2009 and founded Scrum.org, which oversees a parallel series of Professional Scrum accreditations [6].

Since 2009, a public document called The Scrum Guide officially defines Scrum. It had been revised 5 times, with the current version in November 2017 [7].

In 2018 Schwaber and the community Scrum.org together with Kanban community leaders published the Kanban guide for Scrum teams [8].

In a specified literature, there are defined terminology, features of the Scrum organization, its advantages and disadvantages in comparison with the traditional approach to the organization of labor process. Therefore, we meet the following definitions of Scrum.

Scrum is an approach that allows you to solve complex adaptive problems, and at the same time productively and creatively develop products of the highest quality.

SCRUM (SCRibing Unified Methodology or SCRapbooking Unified Methodology or Sprint Continuous Rugby Unified Methodology) is a set of principles, values, policies, rituals, artifacts, based on scribing and scrapbooking, on which the process of SCRUM development is built, allowing to provide in rigidly fixed and small-time iterations, called sprints, for the end user a working product with new business opportunities, for which the greatest priority is determined [9].

Scrum is a framework for developing and sustaining complex products [10].

Scrum is a process approach that has been used to manage work on complex products since the early 1990s.

Scrum is not a process, a technique, or a definitive method. It is rather a technology that allows a variety of processes and techniques to be applied. Scrum demonstrates relative effectiveness of the individual way of product management and work techniques, encouraging enterprise's management to continuously improve product, team and work environment [11].

Scrum is considered to be particularly effective for iterative and incremental knowledge transfer. Therefore, in today's market environment, Scrum is used both for the development of software and hardware, built-in software, networks of interactive functions, autonomous control machines, and for the support of complex construction projects, including the management of marketing activities of construction enterprises.

Formulating the purposes of the article. Questions of Scrum-technology formation were reflected both in the press and online publications, but the question of technology integration into other spheres of activity, such as marketing's management of construction enterprises, was ignored by the researchers, which determined the purpose and objectives of this article.

The purpose of the article is to develop and substantiate the theoretical and methodological foundations of the introduction of Scrum-technology in the management of marketing activities of construction enterprises to improve efficiency of orders and ensure maximum compliance of the finished product with the requirements of the consumer.

Outline of the main material. The essence of Scrumtechnology lies in a small team. A small team is extremely flexible and adaptive. The benefits of Scrum exist not just for one small team, but for several or many teams, or even networks of teams that develop, produce, operate, and support work and results of thousands of people. They collaborate and interact with the help of smart architecture, development and release environments.

Scrum-technology is based on the theory of control of empirical process or empiricism. Empiricism asserts that knowledge comes with experience, and decision-making must take place on the basis of what is already known. 
Scrum uses an iterative, incremental approach to optimize predictability and risk management.

The authors believe that Scrum can be used to organize a team of a construction enterprise and achieve result more productively and with higher quality by analyzing the work done and correcting the direction of development between iterations. The technology allows the team to select the tasks need to be performed, taking into account business priorities and technical capabilities, as well as to decide how to implement them effectively. This allows you to create the conditions, under which the team works with pleasure and is maximally productive. For example, the ability to independently choose the sequence and volume of work, as well as ways of solving problems without external pressure allows all employees of the construction enterprise permits to feel like active players involved in the process, rather than simple performers, from whom only a clear implementation of orders is required [12].

Scrum-technology focuses on constantly defining of prioritized tasks based on business goals, which increases usefulness and profitability of the project in its early stages. Since it is almost impossible to determine profitability of the project at the initiation, Scrum-technology offers to concentrate on the quality of development and, by the end of each iteration, to have an intermediate product (a separate stage of object creation), which is already valuable and can be used, even if with minimal possibilities.

Scrum-technology is oriented on a quick adapting to changes in requirements, which lets team quickly adapt the product to the needs of the customer. This adaptation is achieved by obtaining feedback on the results of the iteration: having a product after each iteration, that can already be shown and discussed, it is easier to collect information and make the right adjustments, change the priorities of requirements. That is, at each individual stage of construction, the object is viewed by the customer and the team of the construction enterprise, details and possible additions, changes in the project are discussed, and appropriate updatings are made.

Scrum-technology combines such components as: Scrum Teams with corresponding roles, events, artifacts and rules. Each component has its own purpose and is the key to success and use of Scrum-technology.

Roles in Scrum system for construction enterprise are:

1. Product owner is a representative or trustee of the customer. The responsibility of this employee is to provide product requirements in a timely manner, determine release dates and content, effectively manage priorities and adjust requirements to maximize the return on product investment.

2. Scrum master is one of the members of the development team, who participates in the project as a developer. The responsibility of the Scrum master is ensuring of maximum efficiency and productivity of the team, clear interaction between all project participants, a timely solution of all problems that slow down or stop the work of any team member, protecting the team from all external influences during the iteration and ensuring of compliance with the process by all project participants.
3. Scrum-team is a group consisting of 5-9 independent, initiative programmers. The responsibility is to participate in the selection of the iteration goal and determine the result of work [7].

The construction enterprise's Scrum events include four formal meetings (events) to test and adapt each stage of product manufacturing: $\bullet$ Sprint Planning $\bullet$ Daily Scrum - Sprint Review $•$ Sprint Retrospective.

The value of Scrum Artifacts lies in the transparency of the workflow and the ability of verifying and adaptation. Scrum-defined artifacts are specifically designed to ensure maximum clarity of key information and that everyone has a common understanding of the artifact. The main artifacts are:

- Burndown chart displays the completed sprint. It shows remaining unsolved tasks and labor expenditures required to complete them per 21 working days.

- Project backlog is a list of functionality requirements, ordered by their degree of importance to be implemented. The items in this list are called user stories or backlog items. Project backlog is open for editing for all participants of the scrum process. Project backlog is maintained by SCRUM Product Owner.

- Sprint backlog contains functionality selected by a product owner from the project backlog. All functions are divided into tasks, each of which is evaluated by the Scrum team.

- Kanban Board must consist of at least three columns: "To make", "In progress", "Done".

- Sprint Goal is a brief description of business purpose, for which this sprint is performed. The sprint goal helps team to make business-informed decisions. This artifact is necessary for a project team to be able to make their own decisions in the event of alternative solutions to the business problem.

- Product Increment is the finished product at the end of the sprint. It is shown to those who are interested at the demonstration to gather feedback and decide what to do with the product next.

Scrum rules link roles, events, and artifacts, regulating interaction between them. [7]

Three basic principles underlie the implementation of control over the empirical process of Scrum-technology of construction enterprise: transparency, inspection and adaptation.

Transparency. Important aspects of the process should be visible to those responsible for the outcome. Under "transparency" one should mean that such aspects should be defined by common standards; this will allow all participants to have a common understanding. For example: • All participants process should use the same terminology. Those who work and those who evaluate the result should have a common understanding of the "completed" work and the "finished" product.

Inspection. Scrum users should frequently check artifacts and progress toward the Sprint Goal to ensure that unwanted deviations are detected in a timely manner, but inspection should not occur so often as to interfere with work. Inspections are most effective if they are carried out by qualified employees directly during the working process. 
Adaptation. If the inspector concludes from the inspection that one or more aspects of the process deviate from acceptable standards, and that the product, which is still being developed, will be unacceptable, then it is necessary to regulate process or replace resources. Changes should be made as quickly as possible to minimize further deviation from the norm.

The slogan of Scrum is "to analyze and to adapt": analyze what you have received, adapt what exists in a real situation, and then analyze again [13].

The implementation of Scrum-technology at the construction enterprise is carried out with the help of the web system Scrum Time. Scrum Time is a web-based system of project management with workgroup control and a scheduler from several methodologies, including Scrum.

Scrum Time Features: view of current tasks; change of progress of the workflow; the Scrum Board; backlog of tasks; statistics on work control; notes; interactive calendar of events; online messenger; sorting by tags; full reports and graphs.

Services, with which Scrum Time has integration, are Google Drive, Google Calendar.

Abilities of the system Scrum Time [14]:

1. Task management (Management of tasks with a simple and friendly interface);

2. Full reports (Chart of tasks' incinerations, team loads, number of completed SP, percentage of sprint completion);

3. Scrum Board (Visual display of the entire workflow on one page);

4. Google services (Integration with Google Calendar and Google Drive services);

5. Time tracking (Track time you or your team spend on tasks);

6. Messenger (Communication with your team directly from the interface or mobile application);

7. Daily Meeting (Daily work plan);

8. Planning Poker (Estimation of labor costs);

9. User Story (Division of Scrum Board into thematic blocks).

Steps for the implementation of flexible technology in the construction enterprise can be performed in any sequence. The main thing to avoid is the desire to ignore any of them.

Stages of introduction of Scrum-technology in the management of marketing activity of the construction enterprise are presented below.

Stage No. 1. Preparing for the power-sharing process.

The purpose of this stage is to start a process that will reduce the participation of individuals in making important decisions for the company. The elimination of the first person from the process of making operational decisions is one of the basic rules, without which it will be impossible to build a functional self-governing system. The main person in the process has full access to all relevant information, but cannot influence the process [15].

Stage No. 2. Conversation with employees.

The purpose of this stage is to determine what processes a company has specialists of, and where to find them. It is important to remember that specialists are the basis of a self- governing system. A team is a group of specialists who, in the performance of their work, clearly understand the purpose for which it is necessary to achieve, and how to do it. At the same time, the team should be inspired by the tasks that its members face. Only when all the conditions are met, it is possible to speak with confidence about the team [7].

Stage No. 3. Designing of financial model.

The purpose of the stage is to form an understanding of how money is counted in the enterprise. An economic model is a detailed explanation of where money comes from, how certain calculations are made, how the margin is calculated, and so on. Developing a financial model can be time-consuming. Here it is important to form a certain top of the model at the initial stage [7].

Stage No. 4. Specification of task for team.

At this stage, it is important to create prerequisites that will help in the formation of tasks for a particular period. A real team understands the direction it is going and the goal it needs to achieve. When the goals are inaccurate, the company may experience a phenomenon that in the project management is called "micromanagement" (in some literature, it has the definition of "manual management") [16]. At this stage, the director is required to learn how to fix certain goals and objectives in a small time interval [7].

Stage No. 5. Development of the structure of business processes at the highest level

The purpose of this stage is to coordinate with the team the main type of business processes: in what sequence the main blocks are, and what they contain. It is at this stage that the prerequisites for the transition to a new management system appear. Here the main blocks of key tasks based on existing business processes are being created.

Stage No. 6. Ascertainment of restrictions.

The goal of this phase is to give managers more authority to manage their unit. In order to avoid chaos in work, it is important to describe the rules for each participant of the process, how they interact with each other, what powers they have, etc. It is necessary to form a system of "red flags" in the enterprise, which allows you to indicate problems. This tool is very important for implementation of a self-governing system. It allows you to determine "strength" of an employee and indicate to him/her what he/ she can handle on his/her own, and when you need the help of colleagues [7].

Stage No. 7. Formation of a system of motivation.

The purpose of this stage is the formation of what can be considered an assessment of the result of work for all stakeholders. Methods of evaluation of results of work can be absolutely whatsoever. The only condition is that all interested parties must agree with it. In addition, it is necessary that it would be limited by some time interval, as the strongest demotivator is the revision of the assessment post factum [7].

At the end of the first cycle, a working group should be formed, headed by a supervisor. The main activity of this group is scaling up of the existing activity. And it does not matter at all whether it will include top specialists or it will be just good employees [17]. 
The steps for implementing of Scrum-technology on the example of the Ukrainian construction company LLC "Alfapivdenbud":

1. A "Product Owner" must be chosen, it is a person who has a vision of what you are going to achieve in a business organization.

Product owner requirements:

- Availability for Scrum events: sprint planning, product demonstrations, sprint retrospectives;

- Drawing up a list of requirements;

- Availability for clarification of questions;

- Understanding of each requirement in the demand list;

- Trust in team in assessing the complexity of requirements;

- Respect for the Sprint goal. Understanding that the team is only doing planned things. Many things can wait for the next sprints;

- Authority to increase the project budget.

For the role of "Product Owner" it is recommended to attract a professional specialist with a certificate confirming that he/she is a "Project Manager".

2. Then one needs to build a "Team", which will include people who directly perform work. They have to perform skills and knowledge to help bring the owner's idea of product in life.

For the construction enterprise LLC "Alfapivdenbud", it is recommended to involve manager, marketing specialist, developer of project tasks and designer into team. All these specialists are available at the enterprise.

3. It is necessary to choose a "Scrum Master", i.e. someone who will monitor the progress of the project, provide short meetings and help the team to remove obstacles to achieving the goal.

For the role of Scrum Master, it is recommended to attract a professional specialist with a certificate confirming that he/she is a "Project Manager".

4. While starting to work, one needs to create the most packed list of all requirements for product or purpose. Items on this list should be prioritized. The list is called "Product Backlog". It can be evolved and changed throughout the life of project.

The list of requirements is backlog. A backlog in Scrum is a list of product requirements and features ordered by the importance of the tasks. It can contain hundreds of tasks or several of them. "The point of making a backlog is to create the most packed list of requirements for functions of the product. To prioritize, one should figure out what items on the list:

- have the greatest importance in the course of work on the project;

- are the most important thing for customer or future consumer;

- will bring maximum income;

- are the easiest thing to do.

5. Team members must evaluate each item against their own rating system for complexity and cost that will be required to complete it.

6. Then participants, Scrum master and product owner should hold the first Scrum sessions, at which they will schedule a sprint, i.e. a certain time to complete one part of the tasks. The duration of the sprint should not exceed one month. For each sprint, the team earns a certain number of points. The team must constantly strive to surpass in the new sprint the number of accumulated points for the previous sprint, that is, its goal is to surpass constantly their own results: is "to increase the dynamics of performance".

7. So that all participants would be aware of the state of affairs, one may have a Scrum Board with three columns: "Need to do, or backlog"; "In progress"; "Done". On the Board, participants glue stickers with tasks, which in the process of work are alternately moved from the "Backlog" column to the "In progress" column, and then to "Done".

8. Every day Scrum meeting should be held. As Jeff Sutherland puts it, "it's the pulse of the whole Scrum process." Its essence is simple, that is, every day, while moving, fifteen minutes are given for everyone to answer three questions: "What did you do yesterday to help team complete the sprint?", "What are you going to do today to help team complete the sprint?", "What obstacles stand in the way of the team?".

9. At the end of the sprint, team does its inspection, i.e. holds a meeting, at which participants tell what has been done for the sprint.

Experience shows that the use of Scrum-technology for a construction enterprise (on the example of the Ukrainian enterprise LLC "Alfapivdenbud") allows to provide marketing orientation of the construction management process, to maintain a dynamic balance of the construction business organization with the environment, to produce construction products in maximum compliance with customer requirements.

Summary. The main conclusions of the study are:

1. Scrum-technology is quite flexible and adaptive for various fields of activity and can be used in the management of marketing activities of the construction enterprise, as it is evidenced by the Ukrainian experience of its application.

2. The main constituent elements of Scrum-technology are: commands, roles, rules, events, artifacts.

3. The defining principles of Scrum-technology are: transparency, inspection, and adaptation.

4. Execution of Scrum-technology is realized through the use of the web system Scrum Time.

5. The main stages of implementation on $\mathrm{CC}$ are:

- Preparing for the power-sharing process.

- Conversation with employees.

- Designing a financial model.

- Specification of task for team.

- Development of the structure of business processes at the highest level

- Ascertainment of restrictions.

- Formation of a system of motivation.

6. Advantages of Scrum-technology are convenient and operative management of teamwork of employees of the construction enterprise for performance of technologically difficult objects with use of the corresponding motivational actions, such as relative independence of responsible persons for performance of separate sectors of tasks. 


\section{References:}

1. Seleznova O. O. (2017) Rozvytok upravlinnia marketynhovoiu diialnistiu budivelnykh pidpryiemstv v Ukraini : monohrafiia. [ Development of management of construction enterprises ' marketing activity in Ukraine : monograph ]. Odessa State Academy of Civil Engineering and Architecture. 356 p. Available at: http://mx.ogasa.org.ua/handle/123456789/5711 (accessed: 01.09.2019).

2. Leslie Hulet Stahl (1990) Wicked Problems, Righteous Solutions: A Catalog of Modern Engineering Paradigms Yourdon Press Computing Series.

3. OOPSLA Available at: http://www.oopsla.org/2006/ (accessed: 01.09.2019).

4. Schwaber K., Beedle M. (2002) Agile software development with Scrum. Prentice Hall.

5. Maximini Dominik (2015) The Scrum Culture: Introducing Agile Methods in Organizations. Management for Professionals. Cham: Springer. January 8, 2015. Retrieved August 25, 2016. P. 26.

6. Partogi Joshua (2013) Certified Scrum Master vs Professional Scrum Master. Lean Agile Institute. July 7, 2013. Retrieved May 10, 2017.

7. Ken Schwaber, Jeff Sutherland (2017) Scrum Guide. The Definitive Guide to Scrum: The Rules of the Game. Available at: https://www.scrumguides.org/docs/scrumguide/v2017/2017-Scrum-Guide-US.pdf (accessed: 01.09.2019).

8. Scrum.org Introduces Scrum with Kanban Course, Enabling Greater Transparency Among Development Teams. Retrieved March 2, 2018. Available at: https://www.businesswire.com/news/home/20180226005111/en/Scrum.orgIntroduces-Scrum-Kanban-Enabling-Greater-Transparency (accessed: 07.09.2019).

9. Vse chto vam nuzhno znat pro metodologiyu Skram. [All you need to know about Scrum methodology]. Finansovyiy direktor [Financial Director] Available at: https://www.fd.ru/articles/158926-vse-chto-vam-nujno-znat-pro-metodologiyuscrum (accessed: 10.10.2019).

10. Stephanie Ockerman. Maximize Scrum with the Scrum Values. Available at: https://www.scrum.org/resources/blog/ maximize-scrum-scrum-values-focus-part-1-5 (accessed: 06.09.2019).

11. Borisov M. (2007) Scrum: gibkoe upravlenie razrabotkoy. [Scrum: flexible development management]. Otkryityie sistemyi. SUBD. [Open systems. DBMS] № 04. Available at: https://www.osp.ru/os/2007/04/4220063/ (accessed: 06.09.2019)

12. Aleksandr Pushkarev. Gibkaya metodologiya razrabotki «Scrum» [ Flexible methodology of development of "Scrum”]. Available at: https://habrahabr.ru/post/247319/ (accessed: 06.09.2019)

13. Steps to Implementing Scrum for Life. Available at: https://www.scrum.org/resources/5-steps-implementing-scrumlife (accessed: 03.08.2019).

14. Martijn van Asseldonk. How Scrum motivates people. Available at: https://www.scrum.org/resources/blog/howscrum-motivates-people (accessed: 07.09.2019).

15. Kniberg X. (2007) Scrum i XP: zametki s peredovoy. [ Scrum and XP from the trenches ]. C4Media. P. 140.

16. Cohn M. (2011) Scrum: gibkaya razrabotka PO. [Software Development Using Scrum ]. Moscow: Williams. P. 576.

17. Sutherland J. (2016) SCRUM. The art of doing twice the work in half the time. Moskow: Mann, Ivanov and Ferber, $288 \mathrm{p}$.

18. Kenneth Rubin (2016) Osnovyi Scrum: Prakticheskoe rukovodstvo po gibkoy razrabotke PO. [Essential Scrum: A Practical Guide to the Most Popular Agile Process ]. Moscow: Williams. P. 544.

\section{Список літератури:}

1. Селезньова О. О. Розвиток управління маркетинговою діяльністю будівельних підприємств в Україні : монографія. Одеса: Одеська державна академія будівництва та архітектури, 2017. 356 c. URL: http://mx.ogasa.org.ua/ handle/123456789/5711 (дата звернення: 01.09.2019).

2. Leslie Hulet Stahl: Wicked Problems, Righteous Solutions: A Catalog of Modern Engineering Paradigms Yourdon Press Computing Series, 1990.

3. OOPSLA. URL: http://www.oopsla.org/2006/ (дата звернення: 01.09.2019).

4. Schwaber K., Beedle M. Agile software development with Scrum. Prentice Hall, 2002.

5. Maximini D. The Scrum Culture: Introducing Agile Methods in Organizations. Management for Professionals. Cham: Springer. January 8, 2015. Retrieved August 25, 2016. P. 26.

6. Partogi J. Certified Scrum Master vs Professional Scrum Master. Lean Agile Institute. July 7, 2013. Retrieved May 10, 2017.

7. Schwaber K., Sutherland J. Scrum Guide. The Definitive Guide to Scrum: The Rules of the Game. Scrumguides.org URL: https:/www.scrumguides.org/docs/scrumguide/ v2017/2017-Scrum-Guide-US.pdf (дата звернення: 01.09.2019).

8. Scrum.org Introduces Scrum with Kanban Course, Enabling Greater Transparency Among Development Teams (Retrieved March 2, 2018). Businesswire.com URL: https://www.businesswire.com/news/home/ 20180226005111/ en/Scrum.org-Introduces-Scrum-Kanban-Enabling-Greater-Transparency (дата звернення: 01.09.2019).

9. Все что вам нужно знать про методологию Скрам. Финансовый директор. URL: https://www.fd.ru/articles/158926vse-chto-vam-nujno-znat-pro-metodologiyu-scrum (дата звернення: 01.09.2019).

10. Ockerman S. Maximize Scrum with the Scrum Values. Scrum.org URL: https://www.scrum.org/resources/blog/ maximize-scrum-scrum-values-focus-part-1-5. (дата звернення: 01.09.2019).

11. Борисов M. Scrum: гибкое управление разработкой. Открытые системы. СУБД. 2007, № 04. URL: https://www.osp.ru/os/2007/04/4220063/ (дата звернення: 01.09.2019). 
12. Александр Пушкарев. Гибкая методология разработки «Scrum». ХАБР. URL: https://habrahabr.ru/post/247319/ (дата звернення: 01.09.2019).

13. Steps to Implementing Scrum for Life. Scrum.org URL: https://www.scrum.org/resources/5-steps-implementingscrum-life. (дата звернення: 01.09.2019).

14. Martijn van Asseldonk. How Scrum motivates people. Scrum.org URL: https://www.scrum.org/resources/blog/howscrum-motivates-people. (дата звернення: 01.09.2019).

15. Книберг X. Scrum и XР: заметки с передовой. C4Media, 2007. 140 с.

16. Кон М. Scrum: гибкая разработка ПО. Москва : Вильямс, 2011. 576 с.

17. Сазерленд Д. SCRUM. Революционный метод управления проектами. Москва : Манн, Иванов и Фербер, 2016. $288 \mathrm{c}$.

18. Кеннет Рубин. Основы Scrum: Практическое руководство по гибкой разработке ПО. Москва : Вильямс, 2016. $544 \mathrm{c}$

\section{SCRUМ-ТЕХНОЛОГІЯ В УПРАВЛІННІ МАРКЕТИНГОВОЮ ДІЯЛЬНІСТЮ БУДІВЕЛЬНОГО ПІДПРИЄМСТВА}

У статті наведено теоретико-прикладні засади впровадження sстит-технології в управління маркетинговою діяльністю будівельного підприємства. Дано визначення прочесу управління маркетинговою діяльністю будівельного підприємства. Наведена історична довідка появи sсrит-технології в області управління підприємством. Розкрито зміст sстит-технології $і$ обгрунтована ї̈ придатність в управлінні маркетинговою діяльністю будівельного підприємства. Названі та описані основні компоненти sстит-технології, а також принципи ї̈ роботи. Розкрито ролі у Sстит-системі для будівельного підприємства: власник продукту, Sститмайстер, Sсгит-команда. Наведено перелік подій Scrum-технології для будівельного підприємства: планування спринту, щзоенний Scrum, ревю спринту, ретроспектива спринту. Розкрито зміст основних артефактів Scruттехнологї: діаграми згорання задач, журнал побажань проекту, журнал побажань спринту, канбан-дошка, мета спринту, інкремент продукту. Наведено та розкрито сутність трьох основних принципів, щзо лежать в основі реалізації контролю за емпіричним прочесом Скрам-технології будівельного підприємства: прозорість, перевірка та адаптація. Дано короткий опис веб-системи для реалізаџії sстит-технології на будівельному підприємстві. Обтрунтовано основні етапи впровадження sсrит-технологіїв управління маркетинговою діяльністю будівельного підприємства, а саме: 1) підготовка до прочесу розподілу повноважень; 2) бесіда з співробітниками; 3) проектування фінансової моделі; 4) конкретизація завдання для команди; 5) розробка структури бізнес-процесів на найвищому рівні; 6) встановлення обмежень; 7) формування системи мотивації. Показано приклад впровадження Sсгит-технології на українському будівельному підприємстві ТОВ «БК«Альфапівденьбуд» з обгрунтуванням поетапних заходів: обрання «Власника продукту»; збір «Команди»; обрання «Скрам-майстра»; створення максимально повного списку усіх вимог, щзо пред'являються до продукту та мети; оцінка учасниками команди кожного пункту на предмет складності і витрат, які будуть потрібні для його виконання; проведення скрам-зборів; заведення скрам-дошки з трьома колами питань («Потрібно зробити, або беклог»; "В роботі»; «Зроблено»); по завершенні кожного спринту огляд командою результатів та вироблення подальших рекомендацій $і$ планів.

Ключові слова: scrum-технологія, sстит-майстер, sстит-команда, маркетингова діяльність, будівельне підприємство, управління проектами.

\section{SCRUМ-ТЕХНОЛОГИЯ В УПРАВЛЕНИИ МАРКЕТИНГОВОЙ ДЕЯТЕЛЬНОСТЬЮ СТРОИТЕЛЬНОГО ПРЕДПРИЯТИЯ}

В статье наведены теоретико-прикладные основы внедрения sсrит-технологии в управление маркетинговой деятельностью строительного предприятия. Дано определение процесса управления маркетинговой деятельностью строительного предприятия. Приведена историческая справка появления sстит-технологии в области управления предприятием. Раскрыто содержание сути sсrит-технологии и обоснована ее пригодность в управлении маркетинговой деятельностью строительного предприятия. Названы и описаны основные компоненты sсrит-технологии, а также приниипы ее работы. Дано краткое описание веб-системы для реализации sстит-технологии на строчтельном предприятии. Обоснованы основные этапь внедрения sститтехнологии в управление маркетинговой деятельностью строительного предприятия. Показан пример внедрения Sсгит-технологии на украинском строительном предприятии ТОВ «БК «Альфапівденьбуд».

Ключевые слова: scrum-технология, scrum-мастер, scruт-команда, маркетинговая деятельность, строительное предприятие, управление проектами. 